\title{
Belonging and women entrepreneurs: Women's navigation of gendered assumptions in entrepreneurial practice
}

\author{
Valerie Stead, Lancaster University
}

\begin{abstract}
The importance of belonging, of fitting in, feeling included and accepted is implicit in empirical studies of women's entrepreneurship. There remains, however, little direct attention to belonging as a concept. This article is novel in proposing belonging as a mediatory and explanatory concept to better understand the relationship between women entrepreneurs and socially embedded gendered assumptions in entrepreneurial practice. Drawing on social theories of belonging and extant entrepreneurial literature, the article explores what belonging involves for women in the entrepreneurial context to offer a conceptualization of entrepreneurial belonging as relational, dynamic, gendered and in continual accomplishment. Five forms of women's performing of belonging are identified; By proxy, Concealment, Modelling the norm, Tempered disruption and Identity-switching. Illustrating how women both reinforce and challenge gendered norms through strategic and tempered use of legitimacy practices and identity work, these findings also highlight the significance of socio-cultural and political knowledge in efforts to belong.
\end{abstract}




\section{Keywords}

Belonging, women entrepreneurs, gender

\section{Introduction}

Thinking about belonging evokes questions of what it is to fit in or to feel out of place, to be an insider or to be excluded, to feel accepted or to feel marginalized. This article introduces a concept of belonging that encompasses these concerns of acceptance, identity, recognition and inclusion (Marshall, 2002; May, 2011). The article employs this concept to better understand how women navigate gendered assumptions to be seen and feel accepted by others as entrepreneurs, and to become part of and feel attached to an entrepreneurial business and to the broader entrepreneurial community.

Issues of belonging are central in studies of women entrepreneurs, including women's identification as entrepreneurs (Díaz-García and Welter, 2013; Essers and Benschop, 2007, 2009); women's resistance to and lack of alignment with normative entrepreneurial identities (Bruni, Gherardi and Poggio, 2004a; Patterson, Mavin and Turner, 2012); the extent to which women are accepted and included as entrepreneurs in male-dominated 
industries (Godwin, Stevens and Brenner, 2006; Marlow and McAdam, 2012), and more broadly in social networks (Watson, 2012). The concept of belonging, however, has received little attention in the entrepreneurial literature (for notable exceptions see Kondo, 1990 and Lewis, 2012).

Discussions of belonging have largely focused on processes that men and women engage in to be part of a business or part of the wider entrepreneurial and business community such as; setting up an entrepreneurial business (Duberley and Carrigan, 2013; Rotefoss and Kolvereid, 2005); joining or transition into an entrepreneurial business (Mallon and Cohen, 2001; Patterson and Mavin, 2009); creating and gaining access to entrepreneurial networks (Foss, 2010; Carter et al., 2003). This literature alerts us to both individual concerns including gaining legitimacy and acceptance, and of developing an entrepreneurial identity, and to social concerns including how social practices might facilitate women's belonging. Limited research, however, is available on the dynamics of women's belonging, how women navigate the interrelationship between the individual and the social in order to belong. Belonging as a concept that connects the individual to the social (May, 2011) is introduced in this article as a means to explore these inter-relational dynamics.

A key consideration indicated by the literature in examining this interrelationship is gender. In particular, empirical studies that explore gender as socially constructed, rather than tied 
to biological sex (West and Zimmerman, 1987), point to tensions between deeply embedded gendered assumptions in processes of belonging and women's efforts to belong. Ezzedeen and Zikic (2012), for instance, illustrate how subordinates' behaviours affect the way in which women entrepreneurs in the male-dominated technology industry seek legitimation.

Attending to the relationship between the individual and the social, belonging is proposed as a concept to illuminate gendered assumptions and to explore how women deal with those tensions. The article does this by asking: How do we understand belonging in the entrepreneurial context? How does gender operate through entrepreneurial processes of belonging? How do women operate to counter gendered perceptions and which practices do they use to achieve belonging?

Exploring these questions contributes to current debates regarding women, gender and entrepreneurship. Drawing on feminist analysis to theorize belonging in the entrepreneurial context, the article argues its value as an explanatory concept that mediates between socially embedded gendered assumptions and ascriptions and entrepreneurship in relation to women entrepreneurs. A dominant focus in the extant literature on women's experiences of discrete belonging processes implies belonging as a finite process tied to specific entrepreneurial activities. This emphasis limits our understanding of the dynamic, ongoing 
and intertwined 'doing of entrepreneurship and doing of gender' (Bruni, Gherardi and Poggio, 2004a). Shifting focus from separate activities and processes to belonging as a concept encourages more in-depth exploration of the dynamics between individual women entrepreneurs and their social entrepreneurial context. Conceptualising belonging therefore contributes by providing a means to gain insight into the social, political and gendered nature of entrepreneurship (eg. Ahl, 2006; Hamilton, 2013b; Hughes et al., 2012). A narrow focus on discrete processes effectively masks the work that women must engage in to belong. Gaining, and claiming entrepreneurial legitimacy is challenging, requiring identity work that takes into account a dominant male entrepreneurial discourse (Marlow and McAdam, 2013). Extant literature observes different strategies that women use, illustrating different ways in which women seek legitimation and various forms of identity work (Bruni, Gherardi and Poggio, 2004a; Diaz, Garcia and Welter, 2013; Duberley and Carrigan, 2012; Essers and Benschop, 2009). This article extends this literature in two ways. It elaborates how women's use of legitimacy practices and identity work positions them, enabling them or not to belong. It provides additional insight into the temporal and strategic nature of women's identity work, illuminating women's complex use of sociocultural and political knowledge in efforts to belong. 
To develop these arguments, first, the feminist theoretical perspective in this article is presented. Second, the concept of belonging is discussed and a concept of gendered entrepreneurial belonging offered, together with five important aspects of belonging for women entrepreneurs. The third section analyses how gender operates through entrepreneurial processes of belonging. The following section identifies five forms of performing belonging used by women entrepreneurs. The fourth section provides reflections on this analysis. The conclusions discuss the analysis, and point out the contributions of the study. This is followed by limitations of the study and suggested directions for future research.

\section{A feminist analysis}

This article draws on sociological and feminist understandings of belonging. In response to calls for development of the concept of gender, Marlow, Henry and Carter (2009) propose drawing on other literature in dialogue with feminist theory as a means to develop explanatory theories that can analyze women's experiences of entrepreneurship. This paper draws on different social theorists to develop a conceptualization of gendered entrepreneurial belonging including Bell (1999), Marshall (2002), and May (2011). I also refer to feminist migration studies (Fortier, 2000), that serve to illustrate belonging as a political process that can exclude as well as include. 
Using these ideas I adopt a feminist theoretical perspective to examine belonging in the entrepreneurial context. Entrepreneurial research calls for more explicit use of feminist theory, to alert us to the female experience and to examine how gender impacts entrepreneurs and entrepreneurship (Ahl, 2006; Hughes et al, 2012; Jennings and Brush, 2013). Feminist theory has value in framing this study in its attention to the 'doing' of gender (West and Zimmerman, 1987), that is, how gender is (re)created, negotiated and maintained in particular social or organizational contexts (Broadbridge and Simpson, 2011). Embedded in everyday action (West and Zimmerman, 1987, p.125), gender is viewed as performative, continually produced and reproduced through social interaction, as 'something that is done' (Ahl, 2006, p.612 italics in original). This view does not reject the importance of how assumptions informed by the gender binary 'actively shape normative behaviours and social expectations' (Marlow and McAdam, 2012, p. 658). Rather, it shifts the focus from the individual to the relationship between the individual and the social. This allows consideration of 'how gender is accomplished'(Ahl, 2006, p. 612, italics in the original), how it plays out through structures, processes and practices such as belonging, and its social effects ( Henry, Foss and Ahl, 2015). Grounding debates in feminist theory can, therefore, offer more developed and nuanced analyses of gender on entrepreneuring, 
and how entrepreneurial processes produce and reproduce gendered normative practices (Marlow, Henry and Carter 2009; Rosa et al., 1994).

\section{Developing a concept of gendered entrepreneurial belonging}

This article develops a concept of gendered entrepreneurial belonging by drawing on disparate literatures including studies at the intersection of research on women's entrepreneurship and gender and entrepreneurship. These studies observe the complex role of gender in the practice of women's entrepreneuring (e.g. Brush, de Bruin and Welter 2009; Tedmanson et al., 2012), including how gender works to construct difference through a range of entrepreneurial processes (e.g. Duberley and Carrigan, 2013; Nadin, 2007). An important consideration in conceptualizing gendered entrepreneurial belonging is the multiplicity of methodological approaches across the studies employed in this article. Moroz and Hindle (2012, p. 784) identify how entrepreneurial processes are 'infused with and informed by a multitude of different theoretical or a-theoretical approaches'. Observing a lack of methodological equivalence, they point to the utility of examining what they have in common, the notion of entrepreneurship as process. Similarly, this study uses empirical studies employed as illustrative examples that draw on different theoretical approaches, such as case study (Patterson and Mavin, 2009), and narrative (Essers and Benschop, 2009). The studies are located in different types of entrepreneurial business, including 
family business (e.g. Hamilton, 2006), and female owned businesses (e.g. Harvey, 2005), and in different geographical and socio-cultural contexts (e.g. Díaz-García and Welter, 2013). Following Moroz and Hindle (2012), the unitary theme employed here is attention to issues of belonging, including how women are recognized and accepted as entrepreneurs.

\section{What is belonging?}

This study draws on a range of social theorists to explore belonging in the entrepreneurial context. A key scholar in this regard is May (2011), whose research theorizes belonging as a relational concept. Belonging as a relational concept rejects ideas that isolate the personal from social structures but, rather, recognizes an interdependence and permeability between the personal and the social with 'each affected by the other' (May, 2011, pp. 365-366). This understanding characterizes belonging as fluid and dynamic, embedded in and emerging from the context of pre-existing social practices. Based in everyday activities and social interaction, belonging connects the official, such as contracts of employment that provide entry into an entrepreneurial business, and the unofficial, for example, informal practices which cement group membership. Research by Gatrell et al. (2014), for instance, highlights how the concept of belonging facilitates a transparency in how parents access flexible working. Similarly, in this study, the relational nature of belonging can help to facilitate a transparency in how women accomplish belonging. 
Additional sources that draw attention to important aspects of belonging include Bell (1999) and Marshall (2002).

First, citing Probyn (1996), Bell observes that belonging has an affective dimension and is concerned not only with being but with longing, a yearning to be part of and become aligned to a particular group. When we talk of belonging we are often expressing a sense of belonging that speaks of inclusivity, of feeling 'part of the system' (Anant, 1996, p. 21), and 'being at ease with one's surroundings' (May, 2011, p. 372). Marshall (2002) refers to belonging as 'a step beyond membership', concerned with how we relate to, assimilate, become accepted, recognized and included. In an entrepreneurial context these ideas are helpful in thinking about belonging as more than joining a business, for instance, but also concerned with being accepted into a business. The concept of belonging then helps to explain 'how people can be embedded in a familiar everyday world yet feel they do not belong there' (May, 2011, p. 370 emphasis in the original). These ideas resonate with studies of women entrepreneurs that are concerned to understand how experiences are situated in and shaped by particular socio-cultural contexts (e.g. Al-Dajani and Marlow, 2010).

As such, belonging is not simply a mechanical process, a joining devoid of emotional investment. Rather, belonging involves individual agency, an investment of self and work 
to present as worthy of belonging (May, 2011). Belonging is, therefore, necessarily tied to concerns of identity (Özbilgin and Woodward, 2004). From a sociological perspective selfand social-identities are acknowledged as shaped by and emerging from social sites of interaction, with individuals drawing on 'conventional' social categories (such as black, white, man, woman)' to construct self-identities (Corlett and Mavin, 2014, p. 5). The focus of belonging on the inter-relational space between the individual and social practice enables more dynamic and nuanced understandings of "the interplay of structure and agency, including developed knowledge of identity work'; how identities are produced, embodied and performed (Özbilgin and Woodward, 2004, p. 677).

Second, Bell's (1999) and Marshall's (2002) research highlights belonging as performative, created and recreated through different practices. This (re)creation of belonging can serve to establish and sustain dominant ways of being or thinking. Feminist studies of migration and belonging are illustrative; performing belonging involves engaging in traditional practices that affirm an individual's legitimacy as a member of the community (Fortier, 2000). Engaging in these ritual practices reaffirms the traditional practices as a route to identification. The effect of performing and reproducing traditions creates a collective identity that will serve to support or, conversely, to reject claims to be part of that community. Attention to belonging as performative therefore emphasises belonging as a 
political process, involving practices of legitimation that can work to privilege some while excluding others (Fortier, 2000). Thus, belonging is multidimensional interweaving with social conditions including gender and occupation that can lead to 'hierarchies of belonging' where 'not everyone is allowed to belong' (May, 2011 p. 369).

Fortier (2000) and May (2011) also alert us to how performing belonging involves the use of legitimacy practices and identity work. Belonging is performed across multiple localities including the physical such as geographical locations, organizations or families and the virtual including to particular ideas and values. By performing multiple belongings across multiple localities we are involved in various practices of legitimation and the ongoing creation of multiple identities, for example, moving between family and business; as an entrepreneur, as a woman, as a mother. Belonging as performative can, then, be helpful in exploring how gendered power relations are revealed and sustained through entrepreneurial processes that serve to legitimize or compromise women's identity as entrepreneurs.

The remainder of this article draws on a conceptualization of belonging as relational, complex, dynamic, situated and performative to develop an understanding of how gendered entrepreneurial belonging might work, and as a means to theorize how women perform belonging, as summarized in Figure 1. 
"Insert Figure 1 here"

\section{Belonging, women entrepreneurs and gender}

One notable exception to the scant attention paid to the concept of belonging in the entrepreneurial literature is Kondo's (1990) study of a family owned factory in Japan.

Exploring 'how people envision their belonging' or lack of belonging in relation to the firm and to the family, Kondo highlights how belonging needs to be articulated within a particular context (p. 44). This section highlights five important aspects of belonging for women in the entrepreneurial context.

First, viewing belonging as relational and dynamic alerts us to how material and affective aspects of belonging are not easily separated. Studies of women's experiences identify that gaining entry and acceptance to the entrepreneurial community involves negotiating multiple social barriers in the form of gendered attitudes and practices (Baughn, Chua and Neupert 2006; Fielden and Dawe, 2004). For instance, after transition from organizational to entrepreneurial careers, women are shown to have to continue to manage gendered assumptions that women play supportive rather than leadership roles (Patterson and Mavin, 
2009). Acceptance and recognition are therefore illuminated as continuous ongoing socioemotional processes (Doern and Goss, 2013).

These socio-emotional processes highlight a second aspect of belonging; women's simultaneous involvement in multiple processes of entrepreneurial belonging. Nadin (2007) demonstrates how women in the care sector, for example, work to cement their legitimacy as female business owners with employees, while simultaneously trying to nurture their acceptance as professional colleagues. Engaging in multiple processes of belonging occurs within and outside of the business. Kondo's (1990) research reveals how the family and the business act as centres of belonging and emotional attachment from which to craft business identity.

A third important aspect in the entrepreneurial context is, therefore, how belonging involves ongoing identity work. In Kondo's study, belonging to both business and family is presented as 'active participation not passive membership', a continuous dynamic, mutually constitutive process where business and family identities each influence the other (op cit. p. 152).

Supporting Fortier's (2000) notion of the multilocality of belonging, this interwoven nature of business and family identity work illuminates a fourth aspect. Belonging is often tied to 
domestic and personal lives, concerned with family as much as business (Baines and Wheelock, 1998; Fletcher, 2000). Women in family businesses typically take on the responsibility of family care, managing a constant shifting and balancing between domestic life and business life, both of which are located within the family (Hamilton, 2006).

This dynamic movement between different localities points to a fifth aspect; being an entrepreneur involves multiple and often overlapping belongings. For women, it is a private and a public task. Bruni, Gherardi and Poggio (2004a) show how women pursue legitimation within both the spheres of domestic and business life in order to maintain belonging to the home and to the business. Moving between the public and the private alerts us to broader social practices and relations; for example, the extent to which cultural, religious or social beliefs might constrain or enable women's acceptance and belonging as entrepreneurs (Al-Dajani and Marlow, 2010). Women's belonging in the entrepreneurial context is then illuminated as a complex political process that involves careful negotiation between multiple identities.

\section{How does gender operate through entrepreneurial processes of belonging?}


Exploring what belonging entails for women entrepreneurs highlights how gender operates through entrepreneurial processes in the form of attitudes, practices and norms to impact on women's belonging.

Gendered attitudes, the "values attached to gendered characterizations of feminine and masculine stereotypes' (Marlow and Patton, 2005, p. 718), are shown to play out through succession practices in family and non-family businesses (Martin, 2001; Mirchandani, 1999). Martin's (2001) research observes how women were rarely seen to be identified as successors, in spite of their availability. Reflecting gendered divisions in the family between 'breadwinner' and 'wife and mother', sons in family firms were regarded as 'heirs apparent' typically rewarded with status and a stake in the business, while daughters were rewarded with resources to improve their lifestyle and domestic situation (p. 224). Here, men are viewed as natural successors, they belong to the business, while women are assessed primarily as belonging to the home, promoting a hierarchy of belonging that foregrounds men as entrepreneurs and women as domestic carers.

The literature also highlights how gendered norms, traditional socio-cultural expectations and values that shape our thinking (Bruni, Gherardi and Poggio, 2004a), affect women's belonging. Duberley and Carrigan (2013) illustrate how mumpreneurs embody a conflicted identity between mother and entrepreneur. Enacting 'a dynamic trade-off' that involves 
being less available to the business in order to manage childcare, and less available to the family to maintain the business, results in a 'fragile' entrepreneurial identity and a belief that they are not recognized as 'proper businesspeople' (p. 642, 643). Intersectional studies (eg. Essers and Benschop, 2007 and 2009; Jamali, 2009) also observe the fragility of women's entrepreneurial belonging; how gender interweaves with religious and ethnic norms, such as codes of conduct and dress, to complicate women's practice and identification as entrepreneurs. If women's identification as entrepreneurs is constrained, then their ability to belong to a business or entrepreneurial community is compromised.

\section{Performing belonging}

The discussions in this article have, so far, focused on conceptualizing belonging as relational, dynamic, situated and performative. These ideas are mobilized to explore women's entrepreneurial belonging as continual, complex and gendered. This section explores how women navigate gendered assumptions in order to belong, by theorizing how women's performing of belonging takes different forms, labelled; by proxy; modelling the norm; concealment; tempered disruption; and, identity switching. The term performing belonging is used to denote its performative nature (Bell, 1999), as something that is repeatedly done and redone, rather than something that is. 
While this analysis highlights how women's performing of belonging might be categorized in similar ways, understanding belonging as relational, situated and dynamic recognizes that these forms are neither straightforward nor represent 'how to belong' strategies. Research shows that doing entrepreneurship and doing gender involves moving between different symbolic spaces, such as the domestic and the business (Bruni, Gherardi and Poggio 2004b). Similarly, the entrepreneurial literature highlights how women entrepreneurs often dance between different ways of performing belonging to realize belonging in a material sense (joining a business) and in an affective sense (being and feeling accepted as an entrepreneur).

\section{By proxy}

By proxy denotes accessing entrepreneurship and entrepreneurial networks through a male partner. Here, belonging (both membership and a sense of inclusivity) is conferred to the female entrepreneur through the male partner. The male partner negotiates belonging processes on behalf of the partnership, including access to entrepreneurial networks, presenting the business to the entrepreneurial community or taking a more active people management role in the business in order to gain legitimacy and acceptance. The female partner is positioned as supportive, adopting a publicly secondary role (Baines and Wheelock, 1998). For example, less experienced women entrepreneurs may be more likely 
to work within 'traditional gender boundaries' and choose to partner with male contacts to afford legitimacy in male-dominated industries (Díaz-García and Welter, 2013, p. 397). Studies observe a gendered dimension to network composition and access to networks (Foss, 2010; Greve and Salaff, 2003). Working with male partners may be a helpful 'strategic choice', therefore, in enhancing legitimacy and broadening limited networks (Godwin, Stevens and Brenner 2006, p. 635).

Performing belonging by proxy is, however, problematic in its reinforcement of the gender binary, affirming gendered normative practices, and female subordination as an acceptable and normal activity (Ahl and Marlow, 2012). Individuals are instrumental 'in how organizing takes place and what results from organizing' (Bird and Brush, 2002, p. 43). Abdicating from belonging processes relinquishes control of how belonging is negotiated and its effects. Performing belonging by proxy may offer initial short term benefits for women, however, by reproducing normative assumptions of entrepreneurship as a male activity it may serve only to underscore men's identification as entrepreneurs.

\section{Concealment}

The term concealment is adopted from research by Lewis and Simpson (2010), to describe how women perform belonging by concealing their femininity and/or concealing their 
identity as an entrepreneur. Concealment, rendering oneself less visible, can offer an alternative to being marked out and a means to manage organizational politics (Stead, 2013). Family business research demonstrates how women's entrepreneurial identities are both concealed and actively masked to preserve marital harmony and family relationships (Hamilton, 2006, 2013a). Belonging to the family business is, therefore, granted on condition of identity concealment.

Women entrepreneurs can either conceal their female identity (Lewis, 2006, 2012) or their business identity (Bruni, Gherardi and Poggio, 2004b). Lewis observes how women business-owners assess each other negatively in terms of their appearance, and also how women consciously sublimate their femininity to be closer to the masculinized ideal of the entrepreneur, to 'look like they belong' (Lewis, 2012, p. 224). This suggests that women might be expected to display 'an automatic knowing' of how to behave and present themselves within a business context (Lewis, 2012, p. 228). This knowing includes understanding when to conceal femininity, and what constitutes a 'proper' femininity, 'being female enough to be seen to benefit business but not excessively feminine' (Lewis, 2012, p. 237). This tacit knowledge, of when to sublimate female identity, may afford acceptance and enable belonging, but at the price of perpetuating a male entrepreneurial norm. Women also perform belonging through concealment of entrepreneurial identity. 
Bruni, Gherardi and Poggio's (2004b) study describes how two sisters who run a welding company resist being framed as entrepreneurs. Concealing their roles as business owners, they promote the male engineer who works for them as an authoritative front person for the business, so simultaneously performing belonging by proxy. Masking their entrepreneurial identity offers a route to legitimation and the preservation of acceptance of their engagement within a male business environment. However working to conceal their identity not only denies their belonging, and their achievement as business owners, but also serves to reinforce traditional notions of who might or might not be an entrepreneur, and who is allowed to belong.

\section{Modelling the norm}

The term modelling the norm describes women performing belonging by replicating or reproducing prevailing norms of what constitutes an entrepreneur. While this may involve concealment and masking of female identity, it is primarily concerned with replication of the dominant norm. An emphasis in the entrepreneurial research on differences between male and female entrepreneurs (Jennings and Brush, 2013) encourages a deficit model of female entrepreneurship (Ahl and Marlow, 2012). Individual comparisons imply women are accountable for structures and systems that are not within their control, leading to approaches that 'blame' or promote 'fixing' the woman (Mavin, 2008). Modelling the norm 
might then be interpreted as a 'fix the woman' approach to belonging, a means to fit in which addresses the deficit and provides some degree of acceptance and legitimation. Research by Marlow and McAdam (2012) notes the tension between professional credibility and ascribed femininity, and how women have to fit in to be accepted. In this study of a female high technology entrepreneur, performing belonging involves showing a level of 'toughness' equal to her male counterparts, while also invoking femininity to signal her compliance with feminine norms. The 'interplay between masculinized toughness and sexualised leverage' enables the female entrepreneur to gain 'honorary' male status although being female still marks out her alterity (Marlow and McAdam, 2012, p. 266). While permitted to claim entrepreneurial roles, Marlow and McAdam's (2012) research suggests women can be confined by their gendered categorization and must be careful not to transgress gender ascribed boundaries. Women may be afforded a quasi-legitimacy as entrepreneurs but may not fully belong.

Performing belonging by modelling the norm is reliant on understanding the power relations at play. While performing a masculinized entrepreneurial identity may grant honorary status, this is a precarious status controlled through gendered power relations that privilege some, in this case the male entrepreneurs, while excluding others, the female entrepreneur. Replicating a norm that constrains women's identification as entrepreneurs 
continues to marginalize. Modelling the norm is, therefore, subject to conditions that may just as easily reject as accommodate.

\section{Tempered Disruption}

I coin the term tempered disruption to denote how female entrepreneurs disrupt traditional and normative gendered expectations of what is an 'entrepreneur', and to describe how they temper this disruption in order to belong. Performing belonging by tempered disruption draws on two sources. First, the idea of the tempered radical is well known, portraying someone with organizational commitment who uses their role to disrupt established patterns of behaviour with the aim of engendering change (Meyerson, 2001). The notion of tempered disruption differs; while it may result in social change, its primary goal is to belong.

Second, tempered disruption builds on research by Bruni, Gherardi and Poggio (2004b), that identifies different processes in which men and women engage. In particular it builds on ideas of footing and gender commodification. Footing describes how men and women work to disrupt a particular space, for example how women disrupt the business sphere due to social expectations that they belong to the domestic sphere. Gender commodification describes the exploitation of the symbolic space of gender to disrupt and (re)construct 
market relations, for example, by women acting in ways that are more commonly attributed to men. Tempered disruption extends these ideas by recognizing the risky nature of disruption, and emphasizing a tempered approach that takes risk into account. It therefore illustrates what Fortier (2000) refers to as 'productive tensions' of belonging; how women positioning themselves in opposition to prevailing gendered norms are compromised, afforded acceptance in one context while blocked from admittance in another. McAdam and Marlow's (2013) study of the disruption and transposition of the normative gendered order of men as business leaders and women as supportive 'business wives' is illustrative (p.151). The study identifies how copreneurs of a childcare business work to reconfigure their roles to gain legitimation and acceptance. The female partner disrupts the male entrepreneurial identity norm by being the visible business lead. This disruption is tempered by the female oriented nature of the business. Legitimation and acceptance is afforded to the female lead by a dominant female client base, who feel more comfortable dealing with a woman regarding care of their children. The copreneurs, however, purposefully change roles to deal with the business community, with the male partner becoming the face of the business. Invoking female and male, maternal and business identities to play to gendered assumptions regarding the roles of entrepreneur and carer, 
their identity work legitimates acceptance with different stakeholders including clients and banks.

While disruption can present as challenging the status quo, closer examination reveals it to be carefully tempered. Reliant on socio-cultural contextual understanding, performing belonging by tempered disruption operates within and makes strategic use of gendered assumptions.

\section{Identity-switching}

Identity switching describes women performing belonging by switching between different identities in different contexts. Identity-switching builds on ideas of boundary-keeping (Bruni, Gherardi and Poggio, 2004b), the safeguarding of boundaries and status, and ideas of creative boundary work (Essers and Benschop, 2009), how boundaries are stretched to create agency as an entrepreneur. It extends these ideas by foregrounding how women use contextual knowledge to invoke a particular identity or multiple identities, for example, identity as a woman, as an engineer, as a business owner, in efforts to belong.

For example, Essers and Benschop (2009, p. 418) illustrate how female Islamic entrepreneurs creatively manipulate religious and cultural boundaries to gain agency as female entrepreneurs. This boundary work illuminates women's strategic promotion of 
different identities in different contexts to engender belonging, for instance, making use of a gendered identity to attract clients where another identity in that context, such as their religious identity, may be constraining.

Also illustrative is Harvey's (2005) study that demonstrates how black female hair salon owners switch between class, gender, race and entrepreneurial identities. The women in this study reflect on the difficulties of relying on their social identity as black working class women to establish their business. They observe how, with hindsight, they would choose instead to invoke their entrepreneurial identity to provide them with wider business opportunity.

Identity-switching to perform belonging, then, draws attention to an ability to move between symbolic spaces (Bruni, Gherardi and Poggio, 2004b), by invoking different and sometimes multiple identities in ways that enhance rather than constrain belonging. Performing belonging by identity-switching highlights an accumulated, contextual knowledge of when to switch identities, developed from engaging in belonging processes.

\section{Discussion}

Exploring women's performing of belonging, the active doing of belonging (Özbilgin and Woodward, 2004), has illuminated complex use of legitimacy practices and identity work. 
Promoted primarily as women or mothers, women remain disadvantaged in their lack of alignment with the gender identification of entrepreneurship leading to difficulties being perceived as legitimate entrepreneurs (Hanson and Blake, 2009). The legitimacy practices what women do to gain acceptance - described here are wide-ranging, illustrating legitimation as a power relationship (Marlow and McAdam, 2013). Women negotiate with male partners to access entrepreneurial networks, promote and present male colleagues or employees to gain individual or business legitimation, and deploy femininities and masculinities to be recognized and accepted as an entrepreneur. This analysis has highlighted how engaging in these practices involves the production, embodiment and performance of identity (Özbilgin and Woodward, 2004). Women produce hybrid male/female identities performed as neither too male nor too female in order to be afforded an entrepreneurial identity which enables them to belong (Marlow and McAdam, 2012). Women embody maternal and carer identities to afford them legitimacy as entrepreneurs in traditionally female oriented businesses (McAdam and Marlow, 2013). Women work to conceal entrepreneurial identities and to embody female supporting identities that grant them belonging by proxy (Hamilton, 2006), or work to embody male identities and suppress female identities (Lewis, 2012). The complex use of legitimacy practices and identity work reveals how women, sometimes simultaneously, reinforce and challenge 
gendered power relations. Women are seen to do gender to fit in, reproducing the cultural practices established by gendered norms, and to redo gender, disrupting gendered norms (Díaz-Garcia and Welter, 2013), to gain acceptance as an entrepreneur. These complex gendered dynamics draw attention to a sophisticated level of knowing including; when to conceal or make visible female and entrepreneurial identities; when to mimic masculinized identities; when to disrupt or when to invoke different, and at times multiple, identities to engender belonging. Illuminating how women are both tempered and strategic in their efforts to belong foregrounds women's developed and nuanced awareness of how gender operates within particular contexts to block or enable belonging, of where gendered boundaries reach and the extent to which gendered boundaries can be stretched. Understanding the performing of belonging as less of a deliberate act, not a performance, but rather an ongoing process of doing belonging, evolving from informal learning from everyday practice, opens up possibilities to disrupt embedded gendered assumptions. While women may perform belonging in ways that assume a 'subordinate positioning', (Doern and Goss, 2013) they may also, over time, through developed socio-cultural and political knowledge, invoke a more established entrepreneurial identity to challenge a normative gendered order. 


\section{Conclusions}

Although the importance for women entrepreneurs of fitting in, feeling included and accepted is widely recognised in the entrepreneurial literature, the concept of belonging has received little attention. This article breaks new ground by asking what belonging involves for women entrepreneurs, how gender impacts on belonging, how women counter gendered perceptions and which practices they use to achieve belonging. Responding to these questions, this article contributes to the literature in three ways.

First, the innovative approach of this article, to theorize belonging in the entrepreneurial context with reference to social theory and feminist entrepreneurial studies, shifts our gaze from a typical and bounded focus on discrete processes of belonging, which can imply belonging as fixed and finite. Rather belonging is conceived here as relational, dynamic and in perpetual accomplishment, 'a constant and complex loop between individual (inter)action and social change, both affecting the other' (May, 20011, p.67). Theorizing belonging in this way demonstrates its utility as an explanatory and mediatory concept through which to gain in-depth understanding of the relationship between gender, women entrepreneurs and their efforts to belong. The gendered, political, performative and embedded nature of entrepreneurial belonging is revealed. This offers rich potential for developed understandings of 'doing entrepreneurship and doing gender' (Bruni, Gherardi 
and Poggio, 2004a). Engaging in belonging is illustrated as a core activity for women entrepreneurs, negotiating and finding ways to develop agency within shifting power asymmetries. This study has shown the dynamic territory of quasi-belonging that women are shown to occupy; neither fully included nor excluded, women are seen to engage in multiple belongings and significant identity work to counter gendered assumptions. As such, invoking belonging as a mediatory concept challenges dualistic tendencies, providing us with a critical lens to understand the complexities and interdependencies involved in women's entrepreneurial activity. Emphasizing the relationship between individuals, their agency and their entrepreneurial context, this conceptualization therefore contributes to methodological debates concerned with offering qualitatively focused and contextualized approaches to widen the 'methodological repertoire' in studies of gender and entrepreneurship (Henry, Foss and Ahl, 2015, p. 20).

Second, a focus on the inter-relational space between the individual women entrepreneur and their social entrepreneurial context, has enabled more dynamic and nuanced understanding of the interplay of structure and agency, and also increased understanding of identity work (Özbilgin and Woodward, 2004). Entrepreneurial social structures such as networks are shown as dynamic and political sites of struggle 'over representation and membership' (May, 2011, p.369), that dictate who may or may not belong. Elaborating on 
women's forms of performing belonging demonstrates how their use of legitimacy practices and identity work responds to and emerges from these sites of struggle. Structure and agency are thus illustrated as mutually constitutive (May, 2011). Women are not separate from entrepreneurial social structures or broader social structures, nor are entrepreneurial social structures constructed independently of the self (May, 2011). Previous literature on women's identity work and legitimacy practices has already provided strategies implemented by women entrepreneurs to develop their activity (Bruni, Gherardi and Poggio, 2004b; Diaz, Garcia and Welter, 2013; Essers and Benschop, 2009). This literature also points to women's resistance and lack of alignment with normative entrepreneurial identities (Patterson, Mavin and Turner, 2012). The value and contribution of this explanation of women's performing of belonging is how their use of legitimacy practices and identity work then positions women, enabling them or not to belong to the entrepreneurial community with full legitimacy. Thus, women entrepreneurs' performing of multiple and often hybrid male/female identities illuminates their shifting positioning and identification as entrepreneurs. Importantly, it also alerts us to how women are agentic in working to reposition themselves, to actively open up spaces that disrupt gendered norms and to manage resistance in tempered and strategic ways. 
Third, a developed understanding of the inter-relational dynamics between women entrepreneurs and their social entrepreneurial context adds depth to understandings of the temporal and strategic nature of identity work in relation to women's entrepreneurial belonging. Extant literature highlights how identity work changes over time based on accumulated knowledge that individuals employ. Women with higher status draw on business experience to challenge gendered assumptions and 'redo gender' (Díaz, Garcia and Welter, 2013). Women also employ a contextually embedded sense-making using past experience to understand the present and the future (Duberley and Carrigan, 2012). The contribution of this study is to make this informal learning and its effects more visible. It does this by demonstrating how women's performing of belonging relies upon complex and multi-layered knowing that is not only about the business or past experience, but also about the individuals' positioning within their business in relation to broader macro power relations. Illuminating different forms of performing belonging has revealed how women use accumulated socio-cultural and political knowledge in order to be both tempered and strategic in efforts to belong. This does not deny the conflict or difficulties that women may feel in their identification as 'proper' entrepreneurs (Duberley and Carrigan, 2012). However, it does argue that women become more contextually adept in identity work over time. May (2011, p.369) citing Bottero (2009), writes that the collective understandings on 
which we build a sense of belonging are 'negotiated accomplishments'. Revealing the ways in which women perform belonging shows how, for women entrepreneurs, their negotiated accomplishments constitute an important resource that enables them to understand and operate within the gendered territory of their entrepreneurial context. This finding also has practical implications for women entrepreneurs. Doern and Gosss (2011) show how the emotions of navigating complex power dynamics such as gendered assumptions can act as barriers to entrepreneurial action. To counter this, women at more advanced stages of their career may prove useful mentors in terms of developing socio-cultural and political intelligence for those with less experience.

\section{Limitations of the study and suggestions for future research}

The limitations of this study stem from its focus on extant literature, involving studies from a range of entrepreneurial and socio-cultural contexts, and its focus on one gender (women). This approach is similar to other entrepreneurial studies (e.g. Moroz and Hindle, 2011), and a focus on women is consistent within a feminist analysis (Hughes et al., 2012; Jennings and Brush, 2013). These limitations, however, offer potential to test ideas through empirical research and with regard to women's and men's experiences. Future studies might take aspects of the conceptualization of gendered entrepreneurial belonging to drill 
down into women's and men's entrepreneurial experiences in depth, and in different sociocultural contexts. For example, the breadth of this study limits the extent to which we can understand the effects of different forms of performing belonging. Future empirical studies might adopt post-structuralist and ethnographic methodologies to observe the effects of efforts to belong. Such studies are needed to provide more detailed insight into the gendered dynamics of belonging, including the ways in which men and women work to position and reposition themselves as entrepreneurs over a period of time, and how this (re)positioning produces and reproduces particular understandings of what it is to be an entrepreneur, and what is involved in entrepreneurial activity. There is recognition in the gender and entrepreneurial literature that more qualitative and contextualised research is required (Henry, Foss and Ahl, 2015), and belonging as a mediatory concept has been shown to be of value in illuminating complex gender dynamics. Empirical studies examining the effects of performing belonging might take place in specific entrepreneurial contexts, such as family business or co-preneurial businesses, and in different socio-cultural contexts adding to a limited number of studies that examine how entrepreneurial experience differs across societies (e.g. Al-Dajani and Marlow, 2010; Jamali, 2009). This study has drawn attention to the temporal and strategic nature of women's identity work in belonging to their social entrepreneurial context. Building further on this study and other research 
(Diaz-Garcia and Welter, 2013; Duberley and Carrigan, 2012), future qualitative studies might use narrative techniques to explore women's performing of belonging at different stages of their entrepreneurial career. Such research would offer more nuanced understanding of the socio-cultural and political knowledge that women accumulate to help them in their efforts to belong.

\section{References}

Ahl H (2006) Why research on women entrepreneurs needs new directions.

Entrepreneurship Theory and Practice 30(5): 595-621.

Ahl H and Marlow S (2012) Exploring the dynamics of gender, feminism and entrepreneurship: advancing debate to escape a dead end? Organization 19(5): 543-562.

Al-Dajani H and Marlow S (2010) Impact of women's home-based enterprise on family dynamics: Evidence from Jordan. International Small Business Journal 28(5): 470-486.

Anant S S (1966) Need to Belong. Canadas Mental Health 14(2): 21-27. 
Baines S and Wheelock J (1998) Working for each other: gender, the household and microbusiness survival and growth. International Small Business Journal 17(1): 16-35.

Baughn C, Chua BL and Neupert K (2006) The normative context for women's participation in entrepreneurship: a multi-country study. Entrepreneurship Theory and Practice 30(5): 687-708.

Bell V (1999) Performativity and Belonging: An Introduction. Theory, Culture and Society 16: $1-10$.

Bird B and Brush C (2002) A gendered perspective on organizational creation. Entrepreneurship Theory and Practice 26(3): 41-65.

Bottero W (2009) Relationality and social interaction. British Journal of Sociology 60(2): 399-420.

Broadbridge A and Simpson R (2011) 25 years on: reflecting on the past and looking to the future in gender and management research. British Journal of Management 22(3): 470-483.

Bruni A, Gherardi S and Poggio B (2004a) Entrepreneur-mentality, gender and the study of women entrepreneurs. Journal of Organizational Change Management 17(3): 256-268. 
Bruni A, Gherardi S and Poggio B (2004b) Doing gender, doing entrepreneurship: an ethnographic account of intertwined practices. Gender, Work and Organization 11(4): 406429.

Brush C G (1992) Research on women business owners: past trends, a new perspective and future directions. Entrepreneurship Theory and Practice: 16(4): 5-30.

Brush CG, de Bruin A. and Welter F (2009) A gender-aware framework for women's entrepreneurship. International Journal of Gender and Entrepreneurship 1(1): 8-24.

Carter N, Brush C, Greene P, Gatewood E and Hart M (2003) Women entrepreneurs who break through to equity financing: the influence of human, social and financial capital. Venture Capital: an international journal of entrepreneurial finance 5(1): 1-28.

Corlett S, and Mavin S (2014 in press) Intersectionality, identity and identity work: shared tenets and future research agendas for gender and identity studies . Gender in Management: an international journal.

Diaz García MC and Welter F (2013) Gender identities and practices: Interpreting women entrepreneurs’ narratives. International Small Business Journal 31(4): 384-404. 
Doern R and Goss D (2013) From barriers to barring: Why emotion matters for entrepreneurial development. International Small Business Journal 31(5): 496-519.

Duberley J and Carrigan M (2013) The career identities of 'mumpreneurs': Women's experiences of combining enterprise and motherhood. International Small Business Journal 31(6): 629-651.

Essers C and Benschop Y (2007) Enterprising identities: Female entrepreneurs of Moroccan or Turkish origin in the Netherlands. Organization Studies 28(1): 49-69.

Essers C and Benschop Y (2009) Muslim businesswomen doing boundary work: The negotiation of Islam, gender and ethnicity within entrepreneurial contexts. Human Relations, 62(3): 403-423.

Ezzedeen SR and Zikic J (2012) Entrepreneurial experiences of women in Canadian high technology. International Journal of Gender and Entrepreneurship 4(1): 44-64.

Fielden SL and Dawe A (2004) Entrepreneurship and social inclusion. Women in Management Review 19(3): 139-142. 
Fletcher D (2000) Family and enterprise. In Carter S and Jones-Evans D (eds) Enterprise and Small Business: Principle, Practice and Policy. Harlow, UK: Pearson Education, pp. 155-165.

Fortier AM (2000) Migrant Belongings: Memory, Space, Identity. Oxford: Berg.

Foss L (2010) Research on entrepreneur networks: the case for a constructionist feminist theory perspective. International Journal of Gender and Entrepreneurship 2(1): 83-102.

Gatrell CJ, Burnett SB, Cooper CL and Sparrow P (2014) Parents, perceptions and belonging: exploring flexible working among UK fathers and mothers. British Journal of Management: 155-165.

Godwin LN, Stevens CE, and Brenner NL (2006) Forced to Play by the Rules? Theorizing How Mixed-Sex Founding Teams Benefit Women Entrepreneurs in Male-Dominated Contexts. Entrepreneurship Theory and Practice 30(5): 623-642.

Greve A and Salaff JW (2003) Social networks and entrepreneurship. Entrepreneurship Theory and Practice 28(1): 1-22. 
Hamilton E (2006) Whose story is it anyway? Narrative accounts of the role of women in founding and establishing family businesses. International Small Business Journal 24(3): 253-271.

Hamilton E (2013a) Entrepreneurship across generations: narrative, gender and learning in family business. Cheltenham: Edward Elgar Publishing Limited.

Hamilton E (2013b) The discourse of entrepreneurial masculinities (and femininities), Entrepreneurship and Regional Development 25(1-2): 90-99.

Hanson S and Blake M (2009) Gender and entrepreneurial networks. Regional Studies 43(1): 135-149.

Harvey AM (2005) Becoming Entrepreneurs Intersections of Race, Class, and Gender at the Black Beauty Salon. Gender and Society 19(6): 789-808.

Henry C, Foss L and Ahl H (2015) Gender and entrepreneurship research: A review of methodological approaches. International Small Business Journal DOI:

$10.1177 / 0266242614549779$ 
Hughes KD, Jennings JE, Brush C, Carter S and Welter F (2012) Extending women's entrepreneurship research in new directions. Entrepreneurship Theory and Practice 36(3): $429-442$.

Jamali D (2009) Constraints and opportunities facing women entrepreneurs in developing countries: a relational perspective. Gender in Management: An International Journal 24(4): 232-251.

Jennings JE and Brush CG (2013) Research on women entrepreneurs: challenges to (and from) the broader entrepreneurship literature? The Academy of Management Annals 7(1): 663-715.

Kondo DK (1990) Crafting Selves: Power, Gender and Discourses of Identity in a Japanese Workplace. Chicago: University of Chicago Press.

Lewis P (2006) The quest for invisibility: female entrepreneurs and the masculine norm of entrepreneurship. Gender, Work and Organization 13(5): 453-469.

Lewis P (2012) Post-Feminism and Entrepreneurship: Interpreting Disgust in a Female Entrepreneurial Narrative. In R. Simpson, Slutskaya N, Lewis P and Höpfl H (eds) Dirty Work: Concepts and Identities Hampshire, UK: Palgrave Macmillan, pp. 223-238. 
Lewis P and Simpson R (2010) Revealing and Concealing Gender: Issues of Visibility in Organizations. Hampshire, UK: Palgrave Macmillan.

Mallon M and Cohen L (2001) Time for a Change? Women's Accounts of the Move from Organizational Careers to Self-Employment. British Journal of Management 12(3): 217230.

Marlow S and Patton D (2005) All credit to men? Entrepreneurship, finance, and gender. Entrepreneurship Theory and Practice 29(6): 717-735.

Marlow S, Henry C and Carter S (2009) Exploring the impact of gender upon women's business ownership. International Small Business Journal 27(2): 139-148.

Marlow S, and McAdam M (2012) Analyzing the Influence of Gender Upon HighTechnology Venturing Within the Context of Business Incubation. Entrepreneurship Theory and Practice 36(4): 655-676.

Marshall DA (2002) Behavior, belonging, and belief: A theory of ritual practice. Sociological Theory 20(3): 360-380.

Martin L (2001) More jobs for the boys? Succession planning in SMEs. Women in Management Review 16(5): 222-231. 
Mavin, S. (2008). Queen bees, wannabees and afraid to bees: no more 'best enemies' for women in management? British Journal of Management, 19(s1), S75-S84.

May V (2011) Self, belonging and social change. Sociology 45(3): 363-378.

McAdam M and Marlow S (2013) A gendered critique of the copreneurial business partnership: Exploring the implications for entrepreneurial emancipation. The International Journal of Entrepreneurship and Innovation 14(3): 151-163.

Meyerson DE (2001) Tempered Radicals: How People Use Difference to Inspire Change at Work. Boston MA: Harvard Business School Press.

Mirchandani K (1999) Feminist insight on gendered work: new directions in research on women and entrepreneurship. Gender, Work and Organization 6(4): 224-235.

Moroz PW and Hindle K (2012) Entrepreneurship as a process: Toward harmonizing multiple perspectives. Entrepreneurship Theory and Practice 36(4): 781-818.

Nadin S (2007) Entrepreneurial identity in the care sector: navigating the contradictions. Women in Management Review 22(6): 456-467. 
Özbilgin MF and Woodward D (2004) 'Belonging' and 'otherness': sex equality in banking in Turkey and Britain. Gender, Work and Organization 11(6): 668-688.

Patterson N and Mavin S (2009) Women Entrepreneurs Jumping the Corporate Ship and Gaining New Wings. International Small Business Journal 27(2): 173-192.

Patterson N, Mavin S and Turner J (2012). Unsettling the gender binary: experiences of gender in entrepreneurial leadership and implications for HRD.European Journal of Training and Development, 36(7), 687-711.

Probyn E (1996) Outside Belongings. London: Routledge.

Rosa P, Hamilton D, Carter S and Burns H (1994) The impact of gender on small business management: preliminary findings of a British study. International Small Business Journal 12(3): 25-32.

Rotefoss B and Kolvereid L (2005) Aspiring, nascent and fledgling entrepreneurs: an investigation of the business start-up process. Entrepreneurship \& Regional Development 17(2), 109-127.

Stead V (2013) Learning to deploy (in) visibility: An examination of women leaders' lived experiences. Management Learning 44(1): 63-79. 
Tedmanson D, Verduyn K, Essers C and Gartner WB (2012) Critical perspectives in entrepreneurship research. Organization 19(5): 531-541.

Watson J (2012) Networking: Gender differences and the association with firm performance. International Small Business Journal 30(5): 536-558.

West C and Zimmerman DH (1987) Doing gender. Gender and society 1(2): 125-151. 


\begin{tabular}{|c|c|c|c|c|}
\hline $\begin{array}{l}\text { What is belonging? } \\
\text { (from Bell, 1999; Fortier, } \\
\text { 2000; Marshall, 2002; May, } \\
\text { 2011) }\end{array}$ & $\begin{array}{l}\text { Examples of processes of } \\
\text { entrepreneurial } \\
\text { belonging }\end{array}$ & $\begin{array}{l}\text { What does belonging } \\
\text { involve for women } \\
\text { entrepreneurs? }\end{array}$ & $\begin{array}{l}\text { How does gender operate } \\
\text { through entrepreneurial } \\
\text { processes to impact on } \\
\text { women's belonging? }\end{array}$ & $\begin{array}{l}\text { Women's performing of } \\
\text { belonging }\end{array}$ \\
\hline $\begin{array}{l}\text { Relational: the individual } \\
\text { and the social mutually } \\
\text { interact and influence each } \\
\text { other }\end{array}$ & $\begin{array}{l}\text { Belonging processes are } \\
\text { material and affective. } \\
\text { Setting up an } \\
\text { entrepreneurial business } \\
\text { (e.g. Rotefoss and } \\
\text { Kolvereid, 2005 ) } \\
\text { Transition into/joining an }\end{array}$ & $\begin{array}{l}\text { Belonging as a complex and } \\
\text { political process. } \\
\text { Material and affective aspects } \\
\text { of belonging are not easily } \\
\text { separated (e.g. Patterson and } \\
\text { Mavin, 2009) } \\
\text { Women are involved }\end{array}$ & $\begin{array}{l}\text { Gendered attitudes, } \\
\text { practices and norms operate } \\
\text { to create gendered } \\
\text { hierarchies of belonging. } \\
\text { Gendered attitudes call into } \\
\text { question women's } \\
\text { legitimacy in running a } \\
\text { business (e.g. Marlow and }\end{array}$ & $\begin{array}{l}\text { Women's performing of } \\
\text { belonging takes multiple } \\
\text { forms. } \\
\text { By proxy: women access } \\
\text { entrepreneurship and } \\
\text { entrepreneurial networks } \\
\text { through male partners (e.g. } \\
\text { Díaz-García and Welter, 2013) }\end{array}$ \\
\hline
\end{tabular}




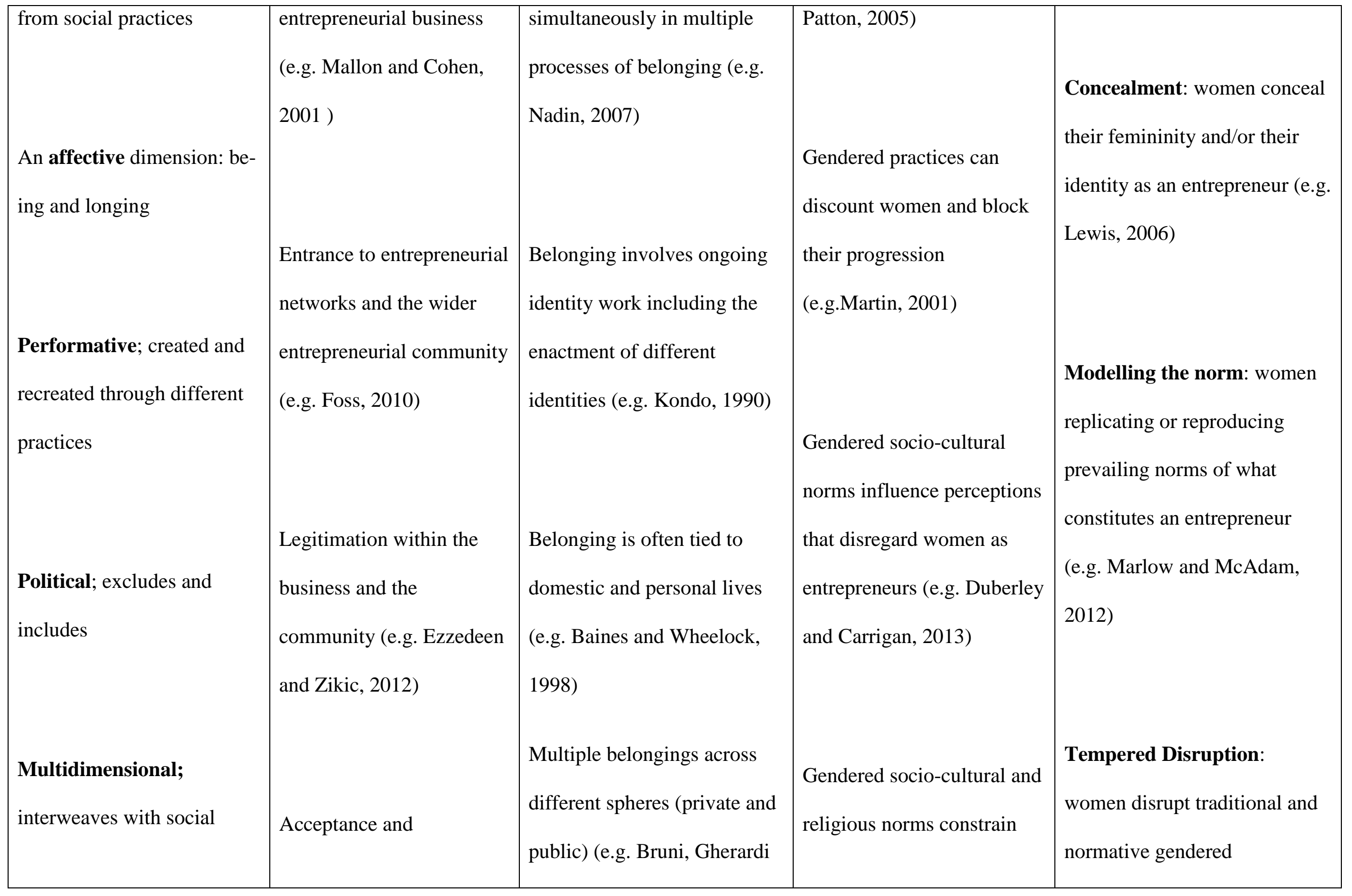




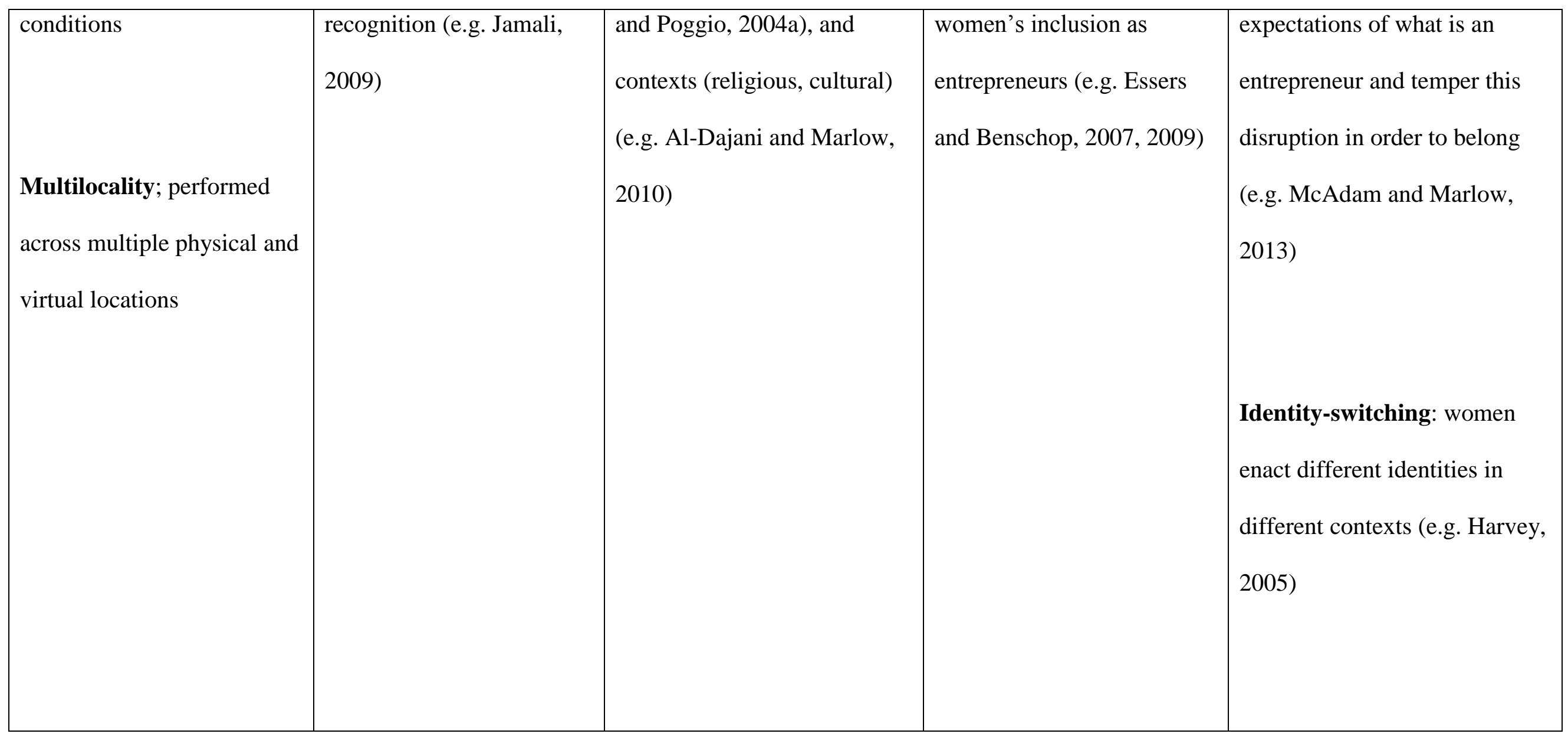

Figure 1. A conceptualization of gendered entrepreneurial belonging 